\title{
Evaluation of Surgical and Systemic Treatment Results in Patients with Ductal Carcinoma In Situ
}

\section{Duktal Karsinoma In Situ Tanılı Hastalarda Cerrahi ve Sistemik Tedavi Sonuçlarının Değerlendirilmesi}

\author{
Abdullah Durhan', @Marlen Suleyman', @Koray Kosmaz', ๑Abdullah Senlikci', @Ender Erguder1, \\ ○Yusuf Murat Bağ'2 , @Mevlüt Recep Pekcici', @Serap Erel'
}

'Ankara Training and Research Hospital, Department of General Surgery, Ankara, Turkey

${ }^{2}$ Van Training and Research Hospital, Department of General Surgery, Van, Turkey

\begin{abstract}
Objective: The aim of this study was to evaluate the surgical method and systemic treatment results, recurrence and mortality rates in patients whose histopathological results were ductal carcinoma in situ (DCIS) following breast surgery in our general surgery clinic.

Material and Method: A retrospective review was made of the preoperative and postoperative histopathological results of all patients who underwent breast surgery in our general surgery clinic between January 2016 and January 2021. The demographic data, clinicopathological features, postoperative systemic treatments, local recurrence (LR) rate, and overall survival (OS) rate of patients whose histopathological results were reported as DCIS were obtained from the data system of our hospital and the national death reporting system.

Results: The study group consisted of 24 female patients with a histopathology result of DCIS. The average age of the patients was $49.96 \pm 10.61$ years. In the localization of the lesions in the breast, 11 (45.8\%) were observed as unifocal, $7(29.2 \%)$ as multifocal and $6(25 \%)$ as multicentric. The most common type of operation was lumpectomy $(n=16$, $66.7 \%$ ). Sentinel lymph node biopsy was performed in 8 patients. The mean follow-up period of the patients after surgery was 32.20 \pm 18.22 months. Anti-estrogen hormone therapy (HT) was applied to 21 (87.5\%) patients and radiotherapy (RT) to $14(58.3 \%)$ after the operation. There was no recurrence in any of the patients and no mortality was observed.

Conclusion: With a multidisciplinary approach and good preoperative staging, as applied in our general surgery clinic, it can be recommended that the most appropriate surgical method is applied, and risk factors determined for DCIS patients. RT is recommended for eligible patients after $\mathrm{BCS}$ and $\mathrm{HT}$ in estrogen receptor+ patients.
\end{abstract}

Keywords: Ductal carcinoma in situ, lumpectomy, mastectomy, sentinel biopsy, radiotherapy, hormone therapy
Öz

Amaç: Bu çalışmada genel cerrahi kliniğimizde meme cerrahisi yapılan hastalarda histopatolojik sonucu duktal karsinoma in situ (DKIS) gelen hastalarımızın cerrahi yöntem ve sistemik tedavi sonuçlarını, rekürens ve mortalite oranlarını değerlendirmeyi amaçladık.

Gereç ve Yöntem: Ocak 2016 ile Ocak 2021 tarihleri arasında, genel cerrahi kliniğiniğimizde meme cerrahisi geçiren tüm hastaların preoperatif ve postoperatif histopatolojik sonuçları incelendi. Histopatolojik sonucu DKIS gelen hastaların demografik verileri, klinikopatolojik özellikleri, reoperasyon sayısı, postoperatif radyoterapi (RT), anti-östrojen hormon tedavisi (HT), lokal rekürens (LR) oranı, ve genel sağkalım (GS) oranı hastanemiz veri datasından ve ulusal ölüm bildirim sisteminden retrospektif olarak incelendi. Bulgular: Çalışma grubu histopaptolojk sonucu DKiS gelen toplam 24 kadın

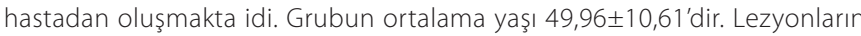
meme içinde yerleşiminde, $11(45,8 \%)^{\prime}$ i i tek odaklı, $7(\% 29,2)$ 'si multifocal ve 6 (\%25)'sı ise multisentrik olarak gözlenmiş̧ir. En sık uygulanan operasyon tipi lumpektomidir ( $n=16,66,7 \%$ ). 8 hastaya sentinel lenf nodu biyopsisi yapılmıştır. Ortanca tümör boyutu 12,5 (4-70) mm'dir. En sık görülen moleküler tip Luminal $A^{\prime}$ dır ( $\left.n=14,58,3 \%\right)$. Lezyona en yakın cerrahi sınır uzaklığı ortanca 5 (0-20) mm'dir. Hastaların cerrahi sonrası ortalama takip

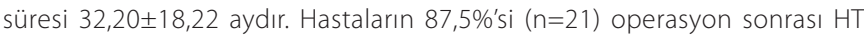
ve 58,3\%'ü (n=14) RT almıştır. Hastaların hiçbirinde nüks gelişmemiştir ve mortalite gözlenmedi.

Sonuç: Genel cerrahi kliniğimiz olarak multidisipliner yaklaşım ve iyi bir preoperatif evreleme ile DKiS hastalarına en uygun cerrahi yöntemi ve risk faktörlerini de değerlendirerek uygun hastalarda meme koruyucu cerrahi sonrası RT ve östrojen reseptörü+ hastalarda HT'yi öneriyoruz.

Anahtar Kelimeler: Duktal karsinoma in situ, lumpektomi, mastektomi, sentinel biyopsi, radyoterapi, hormon tedavisi

Corresponding (illetişim): Abdullah Durhan, Ankara Training and Research Hospital, Department of General Surgery, Altındağ, Ankara, Turkey E-mail (E-posta): durhanabdullah@gmail.com 


\section{INTRODUCTION}

Breast cancer is the major cause of cancer-associated death among women worldwide. ${ }^{[1]}$ With the increase in screening mammography, the rate of early stage breast cancer and ductal carcinoma in situ (DCIS), which is a breast cancer precursor lesion, is gradually increasing. Today, DCIS constitutes 20\% of breast cancer patients. ${ }^{[2]}$ DCIS is a non-invasive breast cancer characterized by atypical ductal cell proliferation within the ducts that make up the breast tissue that do not cross the basement membrane. The 10-year mortality rate is very low, at $1-3 \% .^{[3]}$ Studies have shown that approximately $13 \%$ to $50 \%$ of DCIS lesions can progress to invasive ductal carcinoma (IDC), ${ }^{[4]}$ but is estimated that $70 \%$ of these lesions will not show clinically significant findings. ${ }^{[5]}$ However, which DCIS lesions will become IDC cannot be fully predicted by clinicians. Prognostic factors and nomograms, including tumor grade (low, intermediate and high), comedonecrosis, tumor size, surgical margin status, morphological structure and, in recent years, genetic risk scoring systems are used to predict the aggressive nature of DCIS lesions and help in the selection of the treatment method. ${ }^{[4]}$

There is a wide range of treatment protocols for DCIS disease including mastectomy $(\mathrm{Mx})$, bilateral prophylactic mastectomy (PMx) with or without reconstruction, breast conserving surgery (BCS) with or without radiotherapy (RT) (lumpectomy) and anti-estrogen hormone therapy (HT) (tamoxifen, anastrozole).[6] The high overall survival (OS) rate in DCIS disease and the fact that surgical methods reduce local recurrence (LR) more than OS and increase diseasefree survival (DFS) has led to the questioning of unnecessary aggressive surgery. There are many studies currently being performed in multi centric randomised studies."

The aim of this study was to evaluate the surgical method and systemic treatment results, recurrence and mortality rates in patients with histopathological results of DCIS following BCS and $\mathrm{Mx}$ in our general surgery clinic.

\section{MATERIAL METHOD}

This study was approved by The Ethics Committee of Ankara Training and Research Hospital (approval date and number: 24.02.2021, 2021/21:598). Informed consent was not taken due to the retrospective nature of the study.

The preoperative and postoperative histopathological results of all patients who underwent breast surgery (modified radical mastectomy, simple mastectomy \pm sentinel lymph node biopsy, segmental mastectomy \pm sentinel lymph node biopsy, segmental mastectomy and axillary dissection, excisional biopsy) in the general surgery clinic of our training and research hospital between January 2016 and January 2021 were reviewed. Preoperative and postoperative clinicopathological characteristics of all patients, pathology results, surgery notes, radiology reports, laboratory results and epicrisis reports were reviewed by 3 general surgeons.196 patients diagnosed with invasive breast carcinoma, 164 patients with benign breast disease and patients whose data could not be accessed from the system were excluded from the study. Patients with preoperative imaging and / or tru cut biopsy results and postoperative histopathology results with DCIS were included in the study. Sixteen (66.7\%) patients were diagnosed with mammography-guided lumpectomy after wire marking, and $8(33.3 \%)$ patients with a palpable mass were diagnosed with core biopsy under sonography guidance. The demographic data, operation type, tumor size, localization, histological grade (grade 1, 2, 3), surgical margin status, molecular typing, number of reoperations, postoperative RT, HT, recurrence rate, and OS rate of patients with a histopathological result of DCIS were retrospectively analyzed from the electronic data system of our hospital and the national death reporting system.

\section{Statistical Analysis}

Normal distribution analysis of numerical data was performed using the Shapiro-Wilk test. Numerical data showing normal distribution were expressed as mean \pm standard deviation values, and those that did not show normal distribution were expressed as median (minimum-maximum) values. Categorical data were defined as number (n) and percentage (\%).

\section{RESULTS}

The study group consisted of 24 female patients with a histopathology result of DCIS. The average age of the group was $49.96 \pm 10.61$ years. In pre-operative imaging methods, lesions were most frequently observed in the Breast ImagingReporting and Data System (BIRADS) $4 a(n=15,62.5 \%)$ class. The location of the lesions was evenly distributed in the right and left breast. In the localization of the lesions in the breast, 11 (45.8\%) were observed as unifocal, 7 (29.2\%) as multifocal and $6(25 \%)$ as multicentric. Of the 18 patients with a single focus and multifocal location, 4 were located in the upper outer quadrant, 5 were in the lower outer quadrant, 3 were in the lower inner quadrant, 2 were in the upper inner quadrant, and 4 were centrally located. Two-thirds of the patients were diagnosed from mammography-guided stereotaxic excisional biopsy. The most common type of operation was lumpectomy $(n=16,66.7 \%)$. Mx was applied to $6(25 \%)$ patients with a multicentric location. Sentinel lymph node biopsy was performed in patients who underwent $\mathrm{Mx}$ and in $2(8.3 \%)$ patients who underwent high-risk lumpectomy. The demographic characteristics and clinical results of the patients are shown in Table 1.

Tumor grade 3 was observed in half of the patients, and comedo variant was observed in 9 patients (37.5\%). Median tumor size was 12.5 (4-70) $\mathrm{mm}$. The most common molecular type was Luminal A ( $n=14.58 .3 \%)$. No metastatic lymph node was found in any of the patients who underwent sentinel lymph node biopsy. The closest surgical border distance to the lesion was median $5 \mathrm{~mm}(0-20 \mathrm{~mm})$. The histopathological results of the patients are shown in Table 2. 
Tablo 1. Demographic characteristics and clinical results of the patients

\begin{tabular}{lc}
\hline Characteristics & DCIS (n=24) \\
\hline Age (years) & $49.96 \pm 10.61$ \\
BIRADS n(\%) & $1(4.2)$ \\
0 & $3(12.5)$ \\
3 & $15(62.5)$ \\
$4 a$ & $5(20.8)$ \\
$4 b$ & \\
Tumor localization $\mathbf{n ( \% )}$ & $12(50)$ \\
Right & $12(50)$ \\
Left & \\
Tumor distribution $\mathbf{n ( \% )}$ & $11(45.8)$ \\
Single focus, & $7(29.2)$ \\
Multifocal & $6(25)$ \\
Multicentric & \\
Preoperative biopsy $\mathbf{n ( \% )}$ & $8(33.3)$ \\
Core biopsy & $16(66.7)$ \\
Sterotaxic excisional biopsy & \\
Operation type $\mathbf{n}(\%)$ & $16(66.7)$ \\
Lumpectomy & $2(8.3)$ \\
Lumpectomy+SLNB & $6(25)$ \\
Total mastectomy+SLNB & \\
\hline DCIS: Ductal carcinoma in situ, BIRADS: Breast Imaging-Reporting and Data System, SLNB: Sentinel \\
lymph node biopsy
\end{tabular}

Tablo 2. Histopathological results of the patients.

\begin{tabular}{lc} 
& DCIS ( $\mathbf{n = 2 4 )}$ \\
\hline Histological grade (GR) $\mathbf{n}(\%)$ & \\
$\quad$ GR1 & $4(16.7)$ \\
GR2 & $8(33.3)$ \\
GR3 & $12(50)$ \\
Comedo type (yes) $\mathbf{n}(\%)$ & $9(37.5)$ \\
Tumor size (mm) & $12.5(4-70)$ \\
Molecular subtype $\mathbf{n}(\%)$ & \\
$\quad$ Luminal A & $14(58.3)$ \\
$\quad$ Luminal B & $7(29.2)$ \\
$\quad$ HER-2 positive & $2(8.3)$ \\
Triple negative & $1(4.2)$ \\
Ki-67 (<20) $\mathbf{n}$ (\%) & $22(91.7)$ \\
Number of positive sentinel lymph node & - \\
Number of sentinel lymph nodes & $2(1-5)$ \\
Surgical margin (mm) & $5(0-20)$ \\
\hline DCIS: Ductal carcinoma in situ &
\end{tabular}

The mean follow-up period of the patients after surgery was $32.20 \pm 18.22$ months. The follow-up of the patients was done every 6-12 months for 5 years by medical oncology, radiation oncology, and general surgery specialist with a multidisciplinary approach. The study included an interval history, physical examination, and breast ultrasound every six months. Mammography was performed every 12 months. Postoperatively, HT was applied to $87.5 \%(n=21)$ of the patients and RT to $58.3 \%(n=14)$. Postoperative RT was not given to 2 of the 16 patients as they had comorbid diseases and low grade DCIS was the histopathological results. There was no recurrence in any of the patients and no mortality was observed. Reoperation was performed in 4 patients (16.6\%) because surgical margin negativity could not be achieved. The postoperative follow-up results of the patients are shown in Table 3.
Tablo 3. Postoperative follow-up results of patients.

\begin{tabular}{lc} 
Hormone replacement therapy (yes) $\mathbf{n}(\%)$ & DCIS ( $\mathbf{n = 2 4 )}$ \\
Radiotherapy (yes) $\mathbf{n}(\%)$ & $21(87.5)$ \\
Recurrence (yes) $\mathbf{n}(\%)$ & $14(58.3)$ \\
Mortality (yes) $\mathbf{n}(\%)$ & $0(0)$ \\
Reoperation (yes) $\mathbf{n}(\%)$ & $0(0)$ \\
Reoperation type $\mathbf{n}(\%)$ & $7(29.2)$ \\
$\quad$ Reexcision & $2(8.3)$ \\
$\quad$ Mastectomy+SNLB & $2(8.3)$ \\
Follow-up period (months) & $32.20 \pm 18.22$ \\
\hline DCIS: Ductal carcinoma in situ, SLNB: Sentinel lymph node biopsy & \\
\hline
\end{tabular}

\section{DISCUSSION}

With the increasing use of screening mammography methods, the rate of DCIS diagnoses, which is non-invasive breast cancer, is also increasing. Since DCIS is an early stage disease, it is diagnosed from the presence of punctate, linear and branching microcalcification in the ductus on mammography at a high rate, rather than a palpable mass. ${ }^{[7,8]}$ Very occasionally, it presents as a mass on mammography or sonography, or with bloody nipple discharge in Paget's disease. The diagnosis of DCIS should be confirmed by stereotaxic vacuum biopsy, or the second preference of stereotaxic excisional biopsy ${ }^{[9]}$ Magnetic resonance imaging (MRI) is used in DCIS management to evaluate the extent and distribution of the disease and to evaluate the contralateral breast. ${ }^{[10]}$ It is also used for early diagnosis of invasive and non-invasive breast cancer in high-risk lesions. ${ }^{[11]}$ Although MRI has been shown to be significantly more sensitive than mammography for the diagnosis of DCIS, its specificity is lower and non-malignant lesions may be interpreted as malignancy, which may lead to unnecessary interventions. ${ }^{[12,13]}$ In the current study, MRI was also applied to the high-risk patient group to confirm the spread of the disease in the breast and suitability for BCS.

The diagnosis of DCIS after biopsy depends on the experience and interpretation of the pathologist. Since DCIS is a lesion between IDC and ADH, it may be interpreted in favor of ADH or in favor of IDC by pathologists with different levels of expertise. [14] Therefore, in case of radiopathological incompatibility, it may be necessary to obtain a second expert opinion to prevent insufficient or unnecessary aggressive surgery. In the current study, adjuvant treatment (RT and/or HT) was planned for the patients with radiopathological incompatibility after the histopathological results were obtained from a second expert opinion.

Risk factors for IDC can be listed as positive family history, age, obesity, and high lifetime exposure to estrogen. Patients with the same risk factors are also at high risk for DCIS lesions. ${ }^{[11]}$ Although some previous studies have reported that a significant proportion of DCIS lesions do not transform into IDC, many studies have been conducted to determine which DCIS lesions can become IDC, and the various prognostic factors that predict the risk of recurrence after treatment. Clinically, palpable, multifocal localized tumours of increasing size, 
comedo type, high grade and molecular subtype [estrogen receptor (ER) -, progesterone receptor (PR), human epidermal growth factor receptor $2($ HER2) +)] lesions have been shown to be a greater risk in terms of recurrence. ${ }^{[15-17]}$ Nomograms with clinicopathological factors that predict the risk of relapse and IDC in DCIS patients have been developed. The Van Nuys Prognostic Index (VNPI) was the first risk scoring unit to be defined. ${ }^{\left[{ }^{[18]}\right.}$ Later, risk factors were further expanded and the Memorial Sloan-Kettering Nomogram was defined. ${ }^{[19]}$ In recent years, genetic risk scoring nomograms created with cancer genes have been developed, of which OncotypeDx is one. With these scoring systems, studies predicting the need for adjuvant RT treatment have been conducted by calculating the risk of recurrence after BCS treatment. ${ }^{[20]}$ In the current study, molecular subtype luminal A (14; 58.3\%) and small tumor size (median $12.5 \mathrm{~mm}$ ) were the indicators of good prognosis, while comedo variant $(9 ; 37.5 \%$,), grade $3(12 ; 50 \%)$ and We can list multifocal or multicentric (13; $54.16 \%)$ lesions as poor prognostic factors. Especially 4 patients with multifocal localized lesions were reoperated because negative surgical margins could not be achieved in the first operation.

Surgical methods applied in DCIS lesions do not affect the OS of the patient, but have been shown to affect LR rate in a 10-year follow-up study. The most important factor in minimizing LR in DCIS surgery is resection of the mass with negative surgical margins. There is a current trend moving from aggressive surgery to minimally invasive surgery, as a result of advances in imaging, pathology, treatment and tumor biology. The surgical method to be applied is decided as a result of good preoperative clinical staging with a multidisciplinary approach. Multicentric localized tumors $>4 \mathrm{~cm}$ larger than breast size, failure to obtain negative surgical margins after BCS and Mx method are indicated for patient preference. ${ }^{[4,21]}$ In cases where $M x$ is not indicated, the primary approach is BCS. The advantage of Mx surgery compared to BCS surgery is that the LR rate is very low and adjuvant RT treatment is not required. In addition, unlike IDC, early reconstruction surgery can be applied in patients who undergo $\mathrm{Mx}$ because there is no need for RT treatment. [22] In our clinic, Mx operation was preferred for 6 patients with multicentric location detected in preoperative staging. Although BCS was initially selected, as a safe negative surgical margin could not be provided for 4 patients with multifocal localization, 2 mastectomies and 2 re-excision surgeries were applied. Early re-operations are important to be able to provide safe negative surgery as evidenced by the absence of recurrence in the current patients.

Today, sentinel lymph node biopsy (SLNB) is recommended instead of routine axillary dissection in patients without clinical and radiological axillary metastasis in invasive breast cancer surgery. Axillary dissection is performed for patients with positive SLNB, although the American College of Surgeons Oncology Group Z0011 (ACOSOG Z0011) reported 10-year results of no clinically axillary metastasis with $\mathrm{T} 1$ and
T2 invasive breast cancer, even if 1 or 2 SLNBs are positive, and axillary dissection was performed in patients who received RT and systemic treatment after BCS, with no significant difference determined in terms of OS and DFS among those who received or did not receive these treatments. ${ }^{[23]}$ In DCIS lesions, which are non-invasive breast cancer, the rate of axillary metastasis is as low as $1-2 \%$. Randomized studies (NSABP B-17 and B-24) have reported that the risk of nodal recurrence is very low, at a rate of $1 \% .^{[24,25]}$ It is appropriate to perform SLNB in DCIS lesions only in high-risk patients (palpable mass, comedo type, multicentric located) with suspicion of invasive cancer focus and in patients who will undergo $\mathrm{Mx}$ again after surgery. SLNB is not recommended for other lesions. ${ }^{[26]}$ In the current study, routine SLNB was applied to patients who underwent Mx. SLNB was performed in only 2 (8.3\%) patients in the high risk group who underwent BCS, and SLNB was not positive in any of the patients who underwent biopsy.

Surgical margin status has been the subject of many studies of DCIS patients undergoing BCS and is still a matter of current debate. Since DCIS recurrences are $40-50 \%$ IDC, it is very important to obtain a negative surgical margin. In a study where the positive margin and the negative margin were compared, the negative margin width was discussed in terms of ipsilateral IDC recurrence, but the recurrence rate was significantly lower compared to the positive surgical margin. ${ }^{[27]}$ The Federation of French Cancer Centers (FNCLCC) recommended a surgical margin of $3 \mathrm{~mm}$ for DCIS in a multi-center study ${ }^{[28]}$ In a subsequent meta-analysis, it was found that the surgical margin of $2 \mathrm{~mm}$ was significantly lower in patients who underwent BCS and RT, compared to operations performed with a lower surgical margin. ${ }^{[29]}$ The Society of Surgical Oncology-American Society for Radiation Oncology-American Society of Clinical Oncology Consensus Guideline recommends the negative surgical margin width as $2 \mathrm{~mm}$ in DCIS patients undergoing BCS and RT. It has been suggested that the decision for re-operation should be made for patients with negative margins of $<2 \mathrm{~mm}$ by considering other risk factors affecting recurrence. ${ }^{[30]}$ The median value of the surgical margin distance in the current series patients who underwent BCS in our clinic was $5 \mathrm{~mm}$ (range, 0-20 $\mathrm{mm}$ ). Re-operation was performed for 4 patients when safe surgical margins could not be obtained in the first operation.

The $L R$ rate is quite high after BCS. Randomized studies of EORTC, UK / ANZ, SweDCIS, NSABP B-17 were conducted to reduce $L R$ after $B C S$ and determine RT efficiency. The common result of those studies was that adjuvant RT administration after BCS reduced both ipsilateral IDC and DCIS recurrence. ${ }^{[24,31-33]}$ In addition to those studies, the necessity of RT treatment due to the increased morbidity and the fact that RT treatment does not affect the risk of LR in low-risk DCIS lesions has been the subject of studies. In lowrisk DCIS lesions, BCS with a wide negative surgical margin and $B C S+R T$ treatment have been compared and different results have been reported regarding the efficiency of RT 
in low-risk DCIS lesions. ${ }^{[34-36]}$ Therefore, it can be considered that RT should be given after BCS in eligible patients until a definitive protocol defining the low-risk DCIS patient group is established. In the current study, BCS was applied to a total of 16 patients as a result of re-operations. Postoperative RT was not given to 2 of the 16 patients as they had comorbid diseases and low grade DCIS was the histopathological result, so only HT was given. The other 14 patients received RT after BCS.

Studies have been conducted showing the benefit of HT as adjuvant therapy after BCS and RT treatment in DCIS patients. In the NSABP-24 study, it was shown that tamoxifen treatment after BCS+RT treatment in DCIS patients reduced the incidence of ipsilateral and contralateral recurrence, DCIS and IDC in the ER+patient group. This benefit could not be demonstrated in ER- patients. ${ }^{[37]}$ In the treatment of NSABP-35, the efficacy of tamoxifen, an adjuvant therapy, and anastrozole, an aromatase inhibitor, in postmenopausal hormone-positive women was compared. While the recurrence of ipsilateral invasive breast cancer was lower in the anastrozole group aged $<60$ years, both treatments were found to reduce the recurrence and incidence of invasive breast cancer and DCIS at a similar rate in patients aged > 60 years. ${ }^{[38]}$ In the current study, 21 (87.5\%) patients were in Luminal A or B molecular subtype and HT was applied.

\section{CONCLUSION}

DCIS is a non-invasive breast cancer disease and although various risk scoring nomograms have been developed and are in current use, which lesion will progress to IDC cannot be predicted exactly. The increasing rate of diagnosing DCIS with screening mammograms and applying aggressive treatment to low-risk DCIS patients has been criticized in some studies. In addition, the necessity of RT treatment after BCS in low-risk DCIS lesions is still a matter of research. With a multidisciplinary approach and good preoperative staging, RT can be recommended for eligible patients after BCS, and HT for ER+patients by evaluating the most appropriate surgical method and risk factors for DCIS patients.

\section{ETHICAL DECLARATIONS}

Ethics Committee Approval: The study was approved by Ankara Training and Research Hospital Ethics Committee (decision no: 598, date: 24/02/2021).

Informed Consent: Because the study was designed retrospectively, no written informed consent form was obtained from patients.

Referee Evaluation Process: Externally peer-reviewed.

Conflict of Interest Statement: The authors have no conflicts of interest to declare.

Financial Disclosure: The authors declared that this study has received no financial support.
Author Contributions: All of the authors declare that they have all participated in the design, execution, and analysis of the paper, and that they have approved the final version Concept: $A D, M S$ Design:SE, AD, EE, Data Collection and Processing:AD, MRP, KK, $A S$, Analysis and Interpretation: $A D$, YMB, E, AS, Literature Search: AD, MS, AS, KK, Surgical and Medical Practices: SE, AD, MS, MRP, Writing: AD, SE, KK, MS

\section{REFERENCES}

1. Bray F, Ferlay J, Soerjomataram I, et al. Global cancer statistics 2018: GLOBOCAN estimates of incidence and mortality worldwide for 36 cancers in 185 countries. CA Cancer J Clin. 2018;68(6):394-424.

2. DeSantis CE, Ma J, Goding Sauer A, et al. Breast cancer statistics, 2017, racial disparity in mortality by state. CA Cancer J Clin. 2017;67(6):439-48.

3. Elshof LE, Schmidt MK, Rutgers EJT, et al. Cause-specific Mortality in a Population-based Cohort of 9799 Women Treated for Ductal Carcinoma In Situ. Ann Surg. 2018;267(5):952-8.

4. Hong YK, McMasters KM, Egger ME, et al. Ductal carcinoma in situ current trends, controversies, and review of literature. Am J Surg. 2018;216(5):9981003.

5. Vatovec C, Erten MZ, Kolodinsky J, et al. Ductal carcinoma in situ: a brief review of treatment variation and impacts on patients and society. Critical reviews in eukaryotic gene expression. 2014;24(4):281-6.

6. Sprague BL, McLaughlin V, Hampton JM, et al. Disease-free survival by treatment after a DCIS diagnosis in a population-based cohort study. Breast cancer research and treatment. 2013;141(1):145-54.

7. Scoggins ME, Fox PS, Kuerer HM, et al. Correlation between sonographic findings and clinicopathologic and biologic features of pure ductal carcinoma in situ in 691 patients. AJR Am J Roentgenol 2015;204(4):87888.

8. Barreau B, Mascarel Id, Feuga C, et al. Mammography of ductal carcinoma in situ of the breast: Review of 909 cases with radiographic-pathologic correlations. Eur J Radiol 2005;54(1):55-61.

9. Lambert K, Patani N, Mokbel K. Ductal Carcinoma $<\mathrm{i}>\ln \mathrm{Situ}</ \mathrm{i}>$ : Recent Advances and Future Prospects. Int J Surg Oncol 2012;2012:347385.

10. Menell JH, Morris EA, Dershaw DD, et al. Determination of the Presence and Extent of Pure Ductal Carcinoma in Situ by Mammography and Magnetic Resonance Imaging. Breast J 2005;11(6):382-90.

11. Allegra CJ, Aberle DR, Ganschow P, et al. National Institutes of Health State-of-the-Science Conference statement: Diagnosis and Management of Ductal Carcinoma In Situ September 22-24, 2009. J Natl Cancer Inst 2010;102(3):161-9.

12. Kuhl CK, Schrading S, Bieling HB, et al. MRI for diagnosis of pure ductal carcinoma in situ: a prospective observational study. Lancet. 2007;370(9586):485-92.

13. Schouten van der Velden AP, Schlooz-Vries MS, et al. Magnetic resonance imaging of ductal carcinoma in situ: what is its clinical application? A review. Am J Surg. 2009;198(2):262-9.

14. Elmore JG, Longton GM, Carney PA, et al. Diagnostic concordance among pathologists interpreting breast biopsy specimens. JAMA. 2015;313(11):1122-32

15. Kerlikowske K, Molinaro A, Cha I, et al. Characteristics Associated With Recurrence Among Women With Ductal Carcinoma In Situ Treated by Lumpectomy. JNCI: J Natl Cancer Inst 2003;95(22):1692-702.

16. Vicini FA, Recht A. Age at Diagnosis and Outcome for Women With Ductal Carcinoma-In-Situ of the Breast: A Critical Review of the Literature. Journal of Clinical Oncology. 2002;20(11):2736-44.

17. Provenzano E, Hopper JL, Giles GG, et al. Biological markers that predict clinical recurrence in ductal carcinoma in situ of the breast. Eur J Cancer. 2003;39(5):622-30.

18. Silverstein MJ, Lagios MD, Craig PH, et al. A prognostic index for ductal carcinoma in situ of the breast. Cancer. 1996;77(11):2267-74. 
19. Rudloff U, Jacks LM, Goldberg Jl, et al. Nomogram for predicting the risk of local recurrence after breast-conserving surgery for ductal carcinoma in situ. J Clin Oncol. 2010;28(23):3762-9.

20. Solin LJ, Gray R, Baehner FL, et al. A multigene expression assay to predict local recurrence risk for ductal carcinoma in situ of the breast. J Natl Cancer Inst 2013;105(10):701-10.

21. Boyages J, Delaney G, Taylor R. Predictors of local recurrence after treatment of ductal carcinoma in situ: a meta-analysis. Cancer. 1999;85(3):616-28.

22. Tokin C, Weiss A, Wang-Rodriguez J, et al. Oncologic Safety of SkinSparing and Nipple-Sparing Mastectomy: A Discussion and Review of the Literature. Int J Surg Oncol 2012;2012:921821.

23. Giuliano AE, Ballman KV, McCall $L$, et al. Effect of Axillary Dissection vs No Axillary Dissection on 10-Year Overall Survival Among Women With Invasive Breast Cancer and Sentinel Node Metastasis: The ACOSOG Z0011 (Alliance) Randomized Clinical Trial. JAMA. 2017;318(10):918-26.

24. Fisher B, Dignam J, Wolmark $\mathrm{N}$, et al. Lumpectomy and radiation therapy for the treatment of intraductal breast cancer: findings from National Surgical Adjuvant Breast and Bowel Project B-17. J Clin Oncol. 1998;16(2):441-52.

25. Allred DC, Anderson SJ, Paik S, et al. Adjuvant tamoxifen reduces subsequent breast cancer in women with estrogen receptor-positive ductal carcinoma in situ: a study based on NSABP protocol B-24. J Clin Oncol. 2012;30(12):1268-73.

26. Lyman GH, Temin S, Edge SB, et al. Sentinel lymph node biopsy for patients with early-stage breast cancer: American Society of Clinical Oncology clinical practice guideline update. J Clin Oncol. 2014;32(13):1365-83.

27. MacDonald HR, Silverstein MJ, Mabry H, et al. Local control in ductal carcinoma in situ treated by excision alone: incremental benefit of larger margins. Am J Surg. 2005;190(4):521-5.

28. Cutuli B, Fourquet A, Luporsi E, et al. Standards, options and recommendations for the management of ductal carcinoma in situ of the breast (DCIS): Update 2004. Bulletin du Cancer. 2005;92:155-68.

29. Dunne C, Burke J, Morrow M, et al. Effect of Margin Status on Local Recurrence After Breast Conservation and Radiation Therapy for Ductal Carcinoma In Situ. J Clin Oncol : official j Am Soc Clin Oncol 2009;27:161520.

30. Morrow M, Van Zee KJ, Solin LJ, et al. Society of Surgical OncologyAmerican Society for Radiation Oncology-American Society of Clinical Oncology Consensus Guideline on Margins for Breast-Conserving Surgery With Whole-Breast Irradiation in Ductal Carcinoma In Situ. J Clin Oncol. 2016;34(33):4040-6.

31. Bijker N, Meijnen P, Peterse JL, et al. Breast-conserving treatment with or without radiotherapy in ductal carcinoma-in-situ: ten-year results of European Organisation for Research and Treatment of Cancer randomized phase III trial 10853--a study by the EORTC Breast Cancer Cooperative Group and EORTC Radiotherapy Group. J Clin Oncol. 2006;24(21):3381-7.

32. Cuzick J, Sestak I, Pinder S, et al. Effect of tamoxifen and radiotherapy in women with locally excised ductal carcinoma in situ: Long-term results from the UK/ANZ DCIS trial. Lancet Oncol 2011;12:21-9.

33. Holmberg L, Garmo H, Granstrand B, et al. Absolute risk reductions for local recurrence after postoperative radiotherapy after sector resection for ductal carcinoma in situ of the breast. J Clin Oncol. 2008;26(8):1247-52.

34. Lagios MD, Silverstein MJ. Ductal carcinoma in situ. The success of breast conservation therapy: a shared experience of two single institutional nonrandomized prospective studies. Surg Oncol Clin N Am. 1997;6(2):38592.

35. McCormick B, Winter K, Hudis C, et al. RTOG 9804: a prospective randomized trial for good-risk ductal carcinoma in situ comparing radiotherapy with observation. J Clin Oncol. 2015;33(7):709-15.

36. Solin LJ, Gray R, Hughes LL, et al. Surgical Excision Without Radiation for Ductal Carcinoma in Situ of the Breast: 12-Year Results From the ECOGACRIN E5194 Study. J Clin Oncol. 2015;33(33):3938-44.

37. Allred DC, Anderson SJ, Paik S, et al. Adjuvant Tamoxifen Reduces Subsequent Breast Cancer in Women With Estrogen Receptor-Positive Ductal Carcinoma in Situ: A Study Based on NSABP Protocol B-24. J Clin Oncol 2012;30(12):1268-73.
38. Margolese RG, Cecchini RS, Julian TB, et al. Anastrozole versus tamoxifen in postmenopausal women with ductal carcinoma in situ undergoing lumpectomy plus radiotherapy (NSABP B-35): a randomised, doubleblind, phase 3 clinical trial. Lancet. 2016;387(10021):849-56. 